(c) Elsevier/INRA

Original article

\title{
Estimation of crossbreeding parameters between Large White and Meishan porcine breeds. II. Growth before weaning and growth of females during the growing and reproductive periods
}

\author{
JP Bidanel ${ }^{1 *}$, JC Caritez ${ }^{2}, \mathrm{C}_{\text {Legault }}{ }^{1}$ \\ 1 Institut National de la Recherche Agronomique, \\ Station de Génétique Quantitative et Appliquée, Centre de Recherche de Jouy-en-Josas, \\ 78352 Jouy-en-Josas Cedex; \\ 2 Domaine Expérimental du Magneraud, 17700 Surgères, France
}

(Received 26 December 1989; accepted 13 August 1990)

\begin{abstract}
Summary - A crossbreeding experiment using Large White (LW) and Meishan (MS) pig strains was conducted. Direct, maternal and grand-maternal additive genetic effects together with direct, maternal and paternal heterosis effects were estimated for traits during the preweaning, growing and reproductive periods. Weight at birth (WB) and at $21 \mathrm{~d}$ of age (W21) was recorded in 3731 male and female piglets. After weaning at $28 \mathrm{~d}$, 543 females were weighed at 73 (W73) and 154 (W154) d of age. From these, 148 sows were weighed before farrowing from 1st to 5 th parity. Average daily gains were computed from birth to 21 days of age (ADG 0-21), 21 to 73 days of age (ADG 21-73) and 73 to 154 days of age (ADG 73-154). The genetic influence on preweaning traits was mainly maternal in origin. Maternal additive differences between breeds significantly increased with parity of the dam. Average values were $0.33 \pm 0.05 \mathrm{~kg}(26 \%)$ and $1.24 \pm 0.22 \mathrm{~kg}$ $(26 \%)$ in favour of LW for WB and W21 respectively. Maternal heterosis effects were 0.05 $\pm 0.02 \mathrm{~kg}(6 \%)$ for $\mathrm{WB}$ and $0.65 \pm 0.09 \mathrm{~kg}(14 \%)$ for W21. Significant grand-maternal additive and direct heterosis effects were also observed on WB. Adjustment of data for litter size slightly increased additive and heterosis maternal values. After weaning, direct effects became important. Additive differences between breeds rapidly increased during the growing period and averaged $4.1 \pm 1.0 \mathrm{~kg}(18 \%), 22.9 \pm 3.3 \mathrm{~kg}(36 \%)$ and $231 \pm 33 \mathrm{~g} / \mathrm{d}$ (47\%) in favour of LW for W73, W154 and ADG 73-154 respectively. Direct heterosis effects for these traits were $3.7 \pm 0.7 \mathrm{~kg}(15 \%), 19.2 \pm 2.3 \mathrm{~kg}(25 \%)$ and $187 \pm 24 \mathrm{~g} / \mathrm{d}$ $(30 \%)$ respectively. Direct additive differences in favour of LW increased from $58 \pm 9 \mathrm{~kg}$ at the first farrowing to $111 \pm 10 \mathrm{~kg}$ at the fift b one. Direct heterosis effects were similar throughout reproductive life and averaged $27 \pm 3 \mathrm{~kg}(11 \%)$. The other crossbreeding
\end{abstract}

* Correspondence and reprints 
parameters were small and non-significant after weaning, with the exception of maternal heterosis effects, which remained significant until 154 days.

pig / crossbreeding parameter / Chinese breed / growth

Résumé - Estimation des paramètres du croisement entre les races porcines Large White et Meishan. 1. Croissance avant sevrage et croissance des femelles pendant les périodes de croissance et de reproduction. Une expérience de croisement entre des lignées Large White $(L W)$ et Meishan $(M S)$ a été réalisée. Les effets génétiques additifs directs, maternels, grand-maternels ainsi que les effets d'hétérosis directs, maternels et paternels ont été estimés pour les caractères de croissance au cours des périodes d'allaitement, de croissance et de reproduction. Les poids à la naissance $(P N)$ et à $21 j$ (P21) ont été mesurés sur 3731 porcelets mâles et femelles. Après sevrage à $28 j, 543$ femelles ont été pesées à 73 (P73) et 154 (P154) j d'âge. Cent quarante-huit d'entre elles ont ensuite été pesées avant mise bas de la $1^{\text {re }}$ à la $5^{e}$ portée. Les gains moyens quotidiens ont été calculés entre la naissance et $21 j$ d'âge (GMQ 0-21), 21 et $73 j$ d'âge (GMQ 21 73) et de 73 à $154 j$ d'âge (GMQ 73-154). La variabilité génétique des performances avant sevrage était essentiellement d'origine maternelle. Les différences additives maternelles entre races augmentaient de façon significative avec le numéro de portée. Elles s'élevaient en moyenne à $0,33 \pm 0,05 \mathrm{~kg}(26 \%)$ et $1,24 \pm 0,22 \mathrm{~kg}$ (26\%) en faveur de $\mathrm{LW}$ pour $P \mathrm{~N}$ et $P 21$ respectivement. Les effets d'hétérosis maternel s'élevaient à $0,05 \pm 0,02 \mathrm{~kg}(6 \%)$ pour $P N$ et 0,65 $\pm 0,09 \mathrm{~kg}$ (14\%) pour P21. Des effets grand-maternels et d'hétérosis direct significatifs ont également été observés sur PN. L'ajustement des données pour la taille de la portée a légèrement accru les valeurs des effets additifs et d'hétérosis maternel. Après le sevrage, les effets directs devenaient importants. Les différences additives directes entre races ont augmenté rapidement au cours de la croissance après sevrage et atteignaient $4,1 \pm 1,0 \mathrm{~kg}$ (18\%), 22,9 $\pm 3,3 \mathrm{~kg}(36 \%)$ et $231 \pm 33 \mathrm{~g} / \mathrm{j}$ (47\%) en faveur de $\mathrm{LW}$ pour W73, W154 et GMQ 73-154 respectivement. Les effets d'hétérosis directs pour ces caractères s'élevaient à $3,7 \pm 0,7 \mathrm{~kg}(15 \%) ; 19,2 \pm 2,3 \mathrm{~kg}$ (25\%) et $187 \pm 24 \mathrm{~g} / \mathrm{j}(30 \%)$ respectivement. Les différences additives directes en faveur de $L W$ ont augmenté de $58 \pm$ $9 \mathrm{~kg}$ à la première mise bas à $111 \pm 10 \mathrm{~kg}$ à la cinquième mise bas. Les effets d'hétérosis directs sont restés similaires tout au long de la période de reproduction et atteignaient en moyenne $2 \gamma \pm 3 \mathrm{~kg}(11 \%)$. Les autres paramètres du croisement étaient faibles et non significatifs après le sevrage, à l'exception des effets d'hétérosis maternels, qui subsistaient jusqu'à $154 j$.

porcin / paramètres du croisement / race chinoise / croissance

\section{INTRODUCTION}

A limited number of native pig breeds in China exhibit exceptional reproductive ability and could be of great interest for improving sow productivity (Legault and Caritez, 1983; Zhang et al, 1986). Their growth and carcass performance are, however, much lower than those of the most widely used European breeds (Legault et al, 1985). Hence, a natural way to utilize these breeds is to incorporate them as a component of the maternal line in a crossbreeding system. In this context, their economic merit will largely depend on the relative economic weights of productive and reproductive traits.

Various crossbreeding schemes can be implemented in order to take advantage of the high prolificacy of Chinese breeds (Sellier and Legault, 1986). Their relative economic merit can be assessed using the knowledge of a limited number of 
crossbreeding parameters, ie direct, maternal and grand-maternal breed effects, direct, maternal and paternal heterosis effects and the corresponding epistatic recombination loss effects (Dickerson, 1969; 1973).

Preliminary studies conducted in France indicated that the Meishan was the most promising of the 3 Chinese breeds imported (Legault and Caritez, 1983; Legault et al, 1985). Accordingly, French studies have focused on that breed and an experiment was designed to estimate crossbreeding parameters relative to the cross between the Meishan and the main French breed, the Large White, for traits of economic interest.

Estimates of crossbreeding parameters for sow productivity traits were reported by Bidanel et al (1989). This paper deals with the estimation of additive breed effects and heterosis effects on growth performance.

\section{MATERIAL AND METHODS}

\section{Data and experimental design}

The general three-step design of the experiment was described in detail by Bidanel et al (1989). The first step was a complete 2-breed diallel between Meishan (MS) and Large White (LW) breeds, which led to the production of 4 genetic types of females $(\mathrm{MS}, \mathrm{LW} \times \mathrm{MS}, \mathrm{MS} \times \mathrm{LW}, \mathrm{LW})$ and three genetic types of males (MS, LW, F1 = $\mathrm{LW} \times \mathrm{MS}$ or MS $\times \mathrm{LW})$. In the 2 nd step, 22-45 females chosen at random within each of the 4 above-mentioned genetic types were mated to randomly chosen MS, F1 or LW boars (12-21 per group) and produced 12 genetic types of litters. In the 3rd step, randomly chosen females from these 12 genetic types were inseminated with semen from Pietrain boars in 5 successive parities. The choice of breeding animals, including the assignment of females to various experimental designs, was done at weaning. However, all females kept for breeding were raised in the same environment up to $154 \mathrm{~d}$ of age. They were then allotted to the various studies, including the present one.

The data analysed in the present study include growth performance of the 12 genetic types of animals produced in the second step of the experiment. Three successive periods (ie pre-weaning, growing and reproductive periods) were considered.

Weights at birth (WB) and at $21 \mathrm{~d}$ of age (W21) were recorded in 3731 and 3401 piglets respectively. Weights at 73 (W73) and 154 (W154) d of age were recorded in 543 females kept for breeding. From these, 148 gilts were used as dams in the 3rd step of the experiment and weighed before farrowing at each of the 5 parities.

\section{Herd management}

Litters were born in individual farrowing crates. When necessary, some piglets were moved to another crate within the first few $h$ after birth. With very few exceptions, these adoptions were practised within genetic type. At weaning (around $28 \mathrm{~d}$ of age), piglets were brought to a post-weaning building where they were housed in pens of around 30 animals. Three successive creep diets were provided ad libitum to piglets from $5 \mathrm{~d}$ of age. Female piglets kept for breeding were transferred into the 
fattening unit at the age of 10 wks. They were penned in groups of 8 to 10 , with free access to water and to a pelleted diet (3 $200 \mathrm{kcal} \mathrm{DE} / \mathrm{kg}$ and $16.5 \%$ crude protein). Each pen generally included animals from several genetic types. After $154 \mathrm{~d}$ of age, gilts were given a $15 \%$ crude protein and $3000 \mathrm{kcal} \mathrm{DE} / \mathrm{kg}$ at the daily allowance of $1.8 \mathrm{~kg}$ for MS, $2.2 \mathrm{~kg}$ for crossbred and $2.2-2.5 \mathrm{~kg}$ for LW gilts.

With the exception of some LW gilts exhibiting delayed puberty, all young females were bred at 32 wks of age. Sows were then rebred at the first heat after weaning. All sows were fed a diet containing $16 \%$ crude protein and $3100 \mathrm{kcal}$ $\mathrm{DE} / \mathrm{kg}$. This diet was given ad libitum to all lactating sows whereas pregnant sows received a daily amount of $2.0-2.2 \mathrm{~kg}$ for MS, $2.2-2.5 \mathrm{~kg}$ for crossbred and $2.5-2.7 \mathrm{~kg}$ for LW sows. A 3-4 $\mathrm{kg}$ forage complement (beet or alfalfa) was also given during gestation.

\section{Traits and statistical analyses}

Eleven variables were considered: unadjusted birth weight (UWB); birth weight adjusted for the total number of littermates at birth (AWB); unadjusted weight at $21 \mathrm{~d}$ (UW21); weight at $21 \mathrm{~d}$ adjusted for the number of littermates at $21 \mathrm{~d}$ (AW21); unadjusted average daily gain between birth and $21 \mathrm{~d}$ (UADG 0-21); average daily gain between birth and $21 \mathrm{~d}$ adjusted for litter size at birth and at $21 \mathrm{~d}$ (AADG $0-21$ ); average daily gain between 21 and $73 \mathrm{~d}$ (ADG 21-73); weight at $73 \mathrm{~d}$ (W73); average daily gain between 73 and $154 \mathrm{~d}$ (ADG 73-154); weight at 154 d (W154); sow weight before farrowing (SWF). The measurements during the 5 successive parities were considered as repetitions of a single trait.

Crossbreeding parameters were computed from genetic type effects as described by Bidanel et al (1989). A mixed model analysis (Henderson, 1973) was used for the estimation of genetic type effects. The assumed model for preweaning traits was as follows:

$$
Y_{i j k l m n}=\mu+b_{i}+g_{j}+p_{k}+s_{1}+(g p)_{j k}+L_{i j k m}+E_{i j k l m n}
$$

where:

$$
\begin{aligned}
Y_{i j k l m n} & =\text { an observable random variable } \\
\mu & =\text { an unknown constant } \\
b_{i} & =\text { fixed effect of the } i^{\text {th }} \text { farrowing batch }(i=1, \ldots, 37) \\
g_{j} & =\text { fixed effect of the } j^{\text {th }} \text { genetic type }(j=1, \ldots, 12) \\
p_{k} & =\text { fixed effect of the } k^{t h} \text { parity of the dam }(k=1,2,3) \\
s_{1} & =\text { fixed effect of the } l^{\text {th }} \text { sex }(l=1,2) \\
(g p)_{j k} & =\text { interaction between genetic type and parity of the dam } \\
L_{i j k m} & =\text { random litter within farrowing batch, genetic type and parity effect, } \\
& \text { with mean } 0 \text { and known variance } \sigma_{1}^{2} . \\
E_{i j k l m n}= & \text { random residual effect, with mean } 0 \text { and variance } \sigma_{e}^{2} .
\end{aligned}
$$

Two covariables, $i e$ the exact age at measurement (for all traits except birth weights) and the number of littermates nested within litter genetic type (for AWB, AW21, and AADG 0-21) were also included for the analysis of the mentioned traits. The assumed model for traits measured during the growing period was similar to (1), with the exception of sex effect and "number of littermates" covariate. 
Sow weights were analysed according to the following model:

$$
Y_{i j k l m}=\mu+b_{i}+g_{j}+p_{k}+(g p)_{j k}+S_{j p}+E_{i j k l m}
$$

where:

$Y_{i j k l m}, \mu, b_{i}(i=1, \ldots, 50), g_{j}$ and $E_{i j k l m}$ were as in (1).

$P_{k}=$ fixed effect of sow parity $(k=1, \ldots, 5)$

$(g p)_{j k}=$ interaction between genetic type and sow parity

$S_{j p}=$ random sow within genetic type effect, with mean 0 and known variance $\sigma_{s}^{2}$.

Preliminary analyses demonstrated that the interactions between genetic type and sex and the regressions on dam and litter inbreeding coefficients were small and nonsignificant. Consequently they were excluded from the final analyses. The estimated ratio of the residual to litter (or sow) variances was included in the corresponding equations, which were then absorbed. When this ratio is known, the solutions are Best Linear Unbiased Estimates of fixed effects, provided that the model adequately describes the data (Henderson, 1973; Komender and Hoeschele, 1989). In the present case, variances were not known but were estimated from the data with a Restricted Maximum Likelihood method (Patterson and Thompson, 1971). The SAS Varcomp procedure (SAS Institute, 1985) was used for this estimation.

Genetic type effects were then expressed as functions of crossbreeding parameters. The assumed genetic model was as follows:

$$
y=K b+e \quad \text { with } \operatorname{Var}(y)=v
$$

where $y$ is a $12 \times 1$ vector of estimates of genetic type effects and $b$ is an $11 \times 1$ vector of crossbreeding parameters $b^{\prime}=\left(\mu g_{M S}^{\circ} g_{L W}^{\circ} g_{M S}^{m} g_{L W}^{m} g_{M S}^{n} g_{L W}^{n} h^{\circ}\right.$ $h^{m} h^{p} r^{\circ}$ ) where $\mu$ is an unknown constant; $g_{x}^{\circ}, g_{x}^{m}, g_{x}^{n}$ are direct, maternal and grand maternal effects for breed $x\left(x=\mathrm{LW}\right.$ or MS); $h^{\circ}, h^{m}, h^{p}$ are direct, maternal and paternal heterosis effects for the MS $\times \mathrm{LW}$ cross; $r^{\circ}$ is the direct epistatic recombination loss effect. $K$ is a $12 \times 11$ matrix relating $y$ to $b$. Its structure has been detailed by Bidanel et al (1989); $e$ is a $12 \times 1$ vector of residual errors: $v$ is a $12 \times 12$ variance-covariance matrix of $y$. This genetic model is not of full rank, but can be reparameterized in order to estimate contrasts between breed additive effects $g_{M S}^{\circ}-g_{L W}^{\circ}, g_{M S}^{m}-g_{L W}^{m}, g_{M S}^{n}-g_{L W}^{n}$, direct heterosis effect $h^{\circ}$ and the following linear combinations: $h^{m}+1 / 4 r^{\circ}, h^{p}+1 / 4 r^{\circ}$. The last two quantities are most generally referred to as maternal and paternal heterosis effects. Although this terminology is not rigorously correct, we shall follow it on grounds of simplicity. Solutions were obtained by generalized least-squares analysis (Bidanel et al, 1989).

\section{RESULTS}

\section{Analyses of variance}

Probability levels of Fisher statistics are given in table I. All traits showed significant batch effects. However, these effects did not show any consistent seasonal trend. 
Table I. Probability levels of Fisher statistics in analyses of variance.

\begin{tabular}{|c|c|c|c|c|c|c|c|}
\hline \multirow[t]{2}{*}{ Trait 1} & \multicolumn{5}{|c|}{ Source of variation } & \multirow[b]{2}{*}{$\rho^{2}$} & \multirow{2}{*}{$\begin{array}{l}\text { Residual } \\
\text { standard } \\
\text { deviation }\end{array}$} \\
\hline & Batch & Sex & $\begin{array}{l}\text { Parity of } \\
\text { the dam }\end{array}$ & $\begin{array}{l}\text { Genetic } \\
\text { type }\end{array}$ & $\begin{array}{l}\text { Genetic type } \\
x \text { parity }\end{array}$ & & \\
\hline UWB (kg) & $<0.001$ & $<0.001$ & 0.005 & $<0.001$ & 0.009 & 0.34 & 0.20 \\
\hline AWB (kg) & 0.005 & $<0.001$ & 0.048 & $<0.001$ & 0.001 & 0.23 & 0.20 \\
\hline UADG $0-21(\mathrm{~g} / \mathrm{d})$ & $<0.001$ & 0.516 & 0.007 & $<0.001$ & 0.005 & 0.28 & 39 \\
\hline AADG $0-21(\mathrm{~g} / \mathrm{d})$ & 0.001 & 0.500 & 0.035 & $<0.001$ & 0.031 & 0.21 & 39 \\
\hline UW $21(\mathrm{~kg})$ & $<0.001$ & 0.050 & 0.002 & $<0.001$ & 0.003 & 0.28 & 0.91 \\
\hline AW $21(\mathrm{~kg})$ & $<0.001$ & 0.050 & 0.004 & $<0.001$ & 0.018 & 0.21 & 0.91 \\
\hline ADG $21-73(g / d)$ & $<0.001$ & - & 0.730 & $<0.001$ & 0.403 & 0.24 & 45 \\
\hline W $73(\mathrm{~kg})$ & $<0.001$ & - & 0.465 & $<0.001$ & 0.284 & 0.21 & 2.7 \\
\hline ADG 73-154 $(\mathrm{g} / \mathrm{d})$ & $<0.001$ & - & 0.966 & $<0.001$ & 0.055 & 0.21 & 75 \\
\hline W 154 (kg) & $<0.001$ & - & 0.873 & $<0.001$ & 0.075 & 0.22 & 7.6 \\
\hline SWF (kg) & $<0.001$ & - & $<0.001$ & $<0.001$ & $<0.001$ & 0.75 & 10.8 \\
\hline
\end{tabular}

${ }^{1}$ UWB, AWB, UW21: unadjusted and adjusted (for no of littermates) weights at birth and $21 \mathrm{~d}$ of age respectively. UADG 0-21, AADG 0-21: unadjusted and adjusted average daily gains between birth and $21 \mathrm{~d}$ of age respectively. W73, W154: weights at 73 and $154 \mathrm{~d}$ of age respectively. ADG 21-73, ADG 73-154: average daily gains from 21 to $73 \mathrm{~d}$ of age and from 73 to $154 \mathrm{~d}$ of age respectively. SWF: sow weight before farrowing.

$2 \rho$ : correlation between full-sibs (intra-class correlation) for pre- and postweaning traits; correlation between successive parities (repeatability) for sow weight at farrowing.

Males were heavier $(P<0.05)$ at birth than females $(36 \pm 17 \mathrm{~g})$, but did not grow faster before weaning, so that their advantage was no longer significant at 21 days.

The parity of the dam significantly affected preweaning traits. Piglets from second parity litters were heavier at birth and at 21 days and had a higher growth rate $(P<0.05)$ than those from first parity litters, third parity ones being intermediate after birth (differences between second and first parity and between second and third parity litters were respectively $68 \pm 31 \mathrm{~g}$ and $96 \pm 32 \mathrm{~g}$ for UWB; $0.44 \pm 0.12 \mathrm{~kg}$ and $0.25 \pm 0.13 \mathrm{~kg}$ for UW21; $17 \pm 5 \mathrm{~g}$ and $7 \pm 6 \mathrm{~g}$ for UADG 0-21). After adjustment for litter size, no difference was observed between 2nd and 3rd parities whereas AWB, AW21 and AADG 0-21 were lower in first parity piglets. Parity effect varied according to the genetic type, leading to a significant parity $\times$ genetic type interaction. Traits measured during the growing period were not significantly influenced by the parity of the dam. Sow weight gains between farrowings changed curvilinearly with parity $(24 \mathrm{~kg} ; 24 \mathrm{~kg} ; 17 \mathrm{~kg}$ and $11 \mathrm{~kg}$ at $2 \mathrm{nd}$, 3rd, 4th and 5th parities respectively) and exhibited a significant parity $\times$ genetic type interaction. 
The effect of genetic type was highly significant for all traits. Least squares means for traits measured during the preweaning and growing periods are presented in tables II and III respectively. UWB was much lower in MS, F1 $\times$ MS, LW $\times$ MS and F1 $\times(\mathrm{LW} \times \mathrm{MS})$ genetic types (range $1.02-1.13 \mathrm{~kg}$; table II) than in the 8 other genetic types (range 1.21-1.33 kg). UADG 0-21 was $25 \%$ lower and UW21 was $1 \mathrm{~kg}$ less in piglets from MS dams than in the other genetic types. Adjustment for litter size had a limited influence on the ranking of genetic types. The relationship between weights and fraternity size was linear, but not very high. Mean correlation and regression coefficients were 0.33 and $27 \mathrm{~g} /$ piglet at birth, 0.23 and $84 \mathrm{~g} / \mathrm{piglet}$ at $21 \mathrm{~d}$ respectively. However, variations existed between genetic types. Regression coefficients ranged from $3 \mathrm{~g} /$ piglet $(\mathrm{LW}(\mathrm{MS} \times \mathrm{LW}))$ to $54 \mathrm{~g} /$ piglet $(\mathrm{MS}(\mathrm{LW} \times \mathrm{MS})$ ) at birth and from $5 \mathrm{~g} /$ piglet (LW $\times \mathrm{MS})$ to $295 \mathrm{~g} /$ piglet $(\mathrm{MS}(\mathrm{LW} \times \mathrm{MS})$ ) at $21 \mathrm{~d}$. They were not clearly related to the dam genetic type, but tended to be higher for MS sires.

Table II. Least-squares (LS) means for preweaning growth traits.

\begin{tabular}{|c|c|c|c|c|c|c|c|c|}
\hline \multirow{2}{*}{$\begin{array}{l}\text { Litter genetic } \\
\text { type }^{1}\end{array}$} & \multirow[t]{2}{*}{$n^{3}$} & \multicolumn{2}{|l|}{ Trait $^{2}$} & \multirow[t]{2}{*}{$n^{4}$} & \multicolumn{4}{|l|}{$\operatorname{Trait}^{2}$} \\
\hline & & $\begin{array}{l}U W B \\
(\mathrm{~kg})\end{array}$ & $\begin{array}{l}A W B \\
(\mathrm{~kg})\end{array}$ & & $\begin{array}{l}\text { UW21 } \\
(\mathrm{kg})\end{array}$ & $\begin{array}{l}A W 21 \\
(\mathrm{~kg})\end{array}$ & $\begin{array}{l}U A D G \\
0-21(g / d)\end{array}$ & $\begin{array}{l}A A D G \\
0-21(g / d)\end{array}$ \\
\hline MS & 618 & $1.02 \mathrm{~d}$ & $1.02 \mathrm{f}$ & 593 & $4.11 \mathrm{c}$ & $3.93 \mathrm{c}$ & $146 \mathrm{c}$ & $139 \mathrm{c}$ \\
\hline $\mathrm{MS} \times(\mathrm{LW} \times \mathrm{MS})$ & 287 & $1.29 \mathrm{ab}$ & $1.31 \mathrm{ab}$ & 278 & $5.33 \mathrm{ab}$ & $5.46 \mathrm{ab}$ & $193 \mathrm{a}$ & 198 a \\
\hline $3 / 4 \mathrm{MS} \times(\mathrm{MS} \times \mathrm{LW})$ & 300 & $1.22 \mathrm{~b}$ & $1.24 \mathrm{bcd}$ & 286 & $5.26 \mathrm{~b}$ & $5.33 \mathrm{~b}$ & $192 \mathrm{a}$ & $194 \mathrm{a}$ \\
\hline MS F1 $\times$ MS & 318 & $1.07 \mathrm{~d}$ & $1.04 \mathrm{f}$ & 292 & $4.07 \mathrm{c}$ & $4.06 \mathrm{c}$ & $143 \mathrm{c}$ & $143 \mathrm{c}$ \\
\hline $\mathrm{LW} \times \mathrm{MS}$ & 376 & $1.10 \mathrm{~d}$ & $1.08 \mathrm{ef}$ & 343 & $4.14 \mathrm{c}$ & $4.00 \mathrm{c}$ & $144 \mathrm{c}$ & $138 \mathrm{c}$ \\
\hline $\mathrm{MS} \times \mathrm{LW}$ & 119 & $1.33 \mathrm{a}$ & $1.26 \mathrm{abc}$ & 116 & $5.48 \mathrm{ab}$ & $5.38 \mathrm{ab}$ & $198 \mathrm{ab}$ & $196 \mathrm{ab}$ \\
\hline $1 / 2 \mathrm{~F} 1 \times(\mathrm{LW} \times \mathrm{MS})$ & 363 & $1.22 \mathrm{~b}$ & $1.27 \mathrm{abc}$ & 338 & $5.34 \mathrm{ab}$ & $5.42 \mathrm{ab}$ & $196 \mathrm{ab}$ & $197 \mathrm{ab}$ \\
\hline MS F1 $\times(\mathrm{MS} \times \mathrm{LW})$ & 326 & $1.13 \mathrm{~cd}$ & $1.16 \mathrm{de}$ & 295 & $5.25 \mathrm{~b}$ & $5.30 \mathrm{~b}$ & $195 \mathrm{ab}$ & $196 \mathrm{ab}$ \\
\hline $3 / 4 \mathrm{LW} \times(\mathrm{LW} \times \mathrm{MS})$ & 305 & $1.29 \mathrm{ab}$ & $1.33 \mathrm{a}$ & 289 & $5.74 \mathrm{a}$ & $5.77 \mathrm{a}$ & $211 \mathrm{a}$ & $210 \mathrm{a}$ \\
\hline $\mathrm{LW} \mathrm{LW} \times(\mathrm{MS} \times \mathrm{LW})$ & 335 & $1.21 \mathrm{bc}$ & $1.24 \mathrm{bcd}$ & 318 & $5.33 \mathrm{ab}$ & $5.45 \mathrm{ab}$ & $196 \mathrm{ab}$ & $200 \mathrm{ab}$ \\
\hline F1 $\times$ LW & 176 & $1.31 \mathrm{a}$ & $1.28 \mathrm{ab}$ & 170 & $5.28 \mathrm{~b}$ & $5.23 \mathrm{~b}$ & $189 \mathrm{~b}$ & $189 \mathrm{a}$ \\
\hline LW & 187 & $1.26 \mathrm{~b}$ & $1.20 \mathrm{~cd}$ & 164 & $5.29 \mathrm{ab}$ & $5.16 \mathrm{~b}$ & $191 \mathrm{~b}$ & $188 \mathrm{~b}$ \\
\hline $\begin{array}{l}\text { Standard errors } \\
\text { of LS means }\end{array}$ & & $\begin{array}{l}0.03 \text { to } \\
0.05\end{array}$ & $\begin{array}{l}0.03 \text { to } \\
0.05\end{array}$ & & $\begin{array}{l}0.12 \text { to } \\
0.25\end{array}$ & $\begin{array}{l}0.10 \text { to } \\
0.22\end{array}$ & $\begin{array}{l}5 \text { to } \\
10\end{array}$ & $\begin{array}{l}4 \text { to } \\
10\end{array}$ \\
\hline
\end{tabular}

1 LW: Large White MS: Meishan F1: LW $\times$ MS or MS $\times$ LW. The sire breed is mentioned first. ${ }^{2}$ See footnote ${ }^{1}$ of table I for explanation of traits. ${ }^{3}$ No of animals for UWB and AWB. ${ }^{4}$ No of animals for UW21, AW21, UADG 0-21, AADG 0-21.

Differences between genetic types were larger during the postweaning than the preweaning period. Compared to "3/4 LW", ADG 21-73 was 15, 36, 41 and $91 \mathrm{~g} / \mathrm{d}$ 
Table III. Least-squares (LS) means for growth of females during the growing period.

\begin{tabular}{|c|c|c|c|c|c|}
\hline \multirow{2}{*}{$\begin{array}{l}\text { Sow genetic } \\
\text { type }\end{array}$} & \multirow{2}{*}{$\begin{array}{l}\text { No of } \\
\text { animals }\end{array}$} & \multicolumn{4}{|l|}{ Trait ${ }^{2}$} \\
\hline & & $\begin{array}{l}A D G 21-73 \\
(g / d)\end{array}$ & $\begin{array}{l}W 73 \\
(k g)\end{array}$ & $\begin{array}{l}A D G 73-154 \\
(g / d)\end{array}$ & $\begin{array}{l}W 154 \\
(\mathrm{~kg})\end{array}$ \\
\hline MS & 123 & $358 \mathrm{~d}$ & $23.1 \mathrm{e}$ & $495 \mathrm{f}$ & $63.5 \mathrm{f}$ \\
\hline $\begin{array}{l}\quad \mathrm{MS} \times(\mathrm{LW} \times \mathrm{MS}) \\
3 / 4 \mathrm{MS} \times(\mathrm{MS} \times \mathrm{LW}) \\
\text { MS F1 } \times \mathrm{MS}\end{array}$ & $\begin{array}{l}33 \\
26 \\
17\end{array}$ & $\begin{array}{l}420 \mathrm{bc} \\
415 \mathrm{c} \\
405 \mathrm{c}\end{array}$ & $\begin{array}{l}27.8 \mathrm{bcd} \\
27.4 \mathrm{~cd} \\
26.0 \mathrm{~d}\end{array}$ & $\begin{array}{l}676 \mathrm{de} \\
664 \mathrm{de} \\
634 \mathrm{e}\end{array}$ & $\begin{array}{l}82.0 \mathrm{de} \\
81.4 \mathrm{de} \\
77.3 \mathrm{e}\end{array}$ \\
\hline $\begin{array}{l}\mathrm{LW} \times \mathrm{MS} \\
1 / 2 \mathrm{MS} \times \mathrm{LW} \\
\mathrm{MS} \mathrm{F} 1 \times(\mathrm{LW} \times \mathrm{MS}) \\
\mathrm{F} 1 \times(\mathrm{MS} \times \mathrm{LW})\end{array}$ & $\begin{array}{l}52 \\
36 \\
34 \\
31\end{array}$ & $\begin{array}{l}455 \mathrm{a} \\
433 \mathrm{abc} \\
427 \mathrm{abc} \\
430 \mathrm{abc}\end{array}$ & $\begin{array}{l}28.8 \mathrm{abc} \\
28.8 \mathrm{abc} \\
28.5 \mathrm{bc} \\
28.5 \mathrm{bc}\end{array}$ & $\begin{array}{l}786 \mathrm{a} \\
766 \mathrm{ab} \\
713 \mathrm{~cd} \\
722 \mathrm{bcd}\end{array}$ & $\begin{array}{l}92.4 \mathrm{ab} \\
92.8 \mathrm{ab} \\
85.8 \mathrm{~cd} \\
86.8 \mathrm{~cd}\end{array}$ \\
\hline $\begin{array}{l}3 / 4 \mathrm{LW} \times(\mathrm{LW} \times \mathrm{MS}) \\
\mathrm{LW} \mathrm{LW} \times(\mathrm{MS} \times \mathrm{LW}) \\
\mathrm{F} 1 \times \mathrm{LW}\end{array}$ & $\begin{array}{l}64 \\
38 \\
34\end{array}$ & $\begin{array}{l}451 \mathrm{a} \\
446 \mathrm{ab} \\
451 \mathrm{a}\end{array}$ & $\begin{array}{l}30.2 \mathrm{a} \\
29.2 \mathrm{ab} \\
29.4 \mathrm{ab}\end{array}$ & $\begin{array}{l}790 \mathrm{a} \\
792 \mathrm{a} \\
748 \mathrm{ab}\end{array}$ & $\begin{array}{l}94.7 \mathrm{ab} \\
93.6 \mathrm{a} \\
90.4 \mathrm{abc}\end{array}$ \\
\hline LW & 55 & $408 \mathrm{c}$ & $27.4 \mathrm{~cd}$ & $767 \mathrm{ab}$ & $89.5 \mathrm{bc}$ \\
\hline $\begin{array}{l}\text { Standard errors } \\
\text { of LS means }\end{array}$ & & $\begin{array}{l}8 \text { to } \\
16\end{array}$ & $\begin{array}{l}0.5 \text { to } \\
1.0\end{array}$ & $\begin{array}{l}14 \text { to } \\
27\end{array}$ & $\begin{array}{l}1.4 \text { to } \\
2.5\end{array}$ \\
\hline
\end{tabular}

${ }^{1}$ LW: Large White MS: Meishan F1: LW $\times$ MS or MS $\times$ LW. The sire breed is mentioned first. ${ }^{2}$ See footnote (1) of table I for explanation of traits.

lower and W73 was 1.0, 2.5, 2.2 and $6.5 \mathrm{~kg}$ lower in "1/2 MS", "3/4 MS", LW and MS respectively (table III). Within groups with an equal proportion of MS genes, performance was rather homogeneous, except for " $1 / 2 \mathrm{MS}$ " where a significant advantage of $\mathrm{LW} \times \mathrm{MS}$ was noticed.

Differences between genetic types were higher during the 73-154 d period. Compared to "F1", "3/4 LW" and LW that exhibited the highest weight gains, ADG 73-154 was about 60, 115 and $280 \mathrm{~g} / \mathrm{d}$ lower in "F2", "3/4 MS" and MS respectively. The ranking of genetic types was similar for W154, with a difference of more than $30 \mathrm{~kg}$ between extremes. Females sired by crossbred boars always had a lower performance than the other genetic types with the same proportion of MS genes.

With the exception of "F1" and "F2" genetic types, sows with equal proportion of MS genes had very similar weights at farrowing. Hence, 6 groups of genetic types (MS, "3/4 MS", "F1", "F2", "3/4 LW", LW) were considered in figure 1a. Sows kept on growing, though less rapidly, during their whole reproductive life. However, growth patterns varied according to the genetic type. Weight gains of sows tended to lower with increasing proportions of MS genes, particularly in the first 3 parities (figure 1b). The hierarchy of genetic types with respect to adult weight (estimated as the average value of $4 \mathrm{th}$ and 5 th parities) remained almost the same as during 

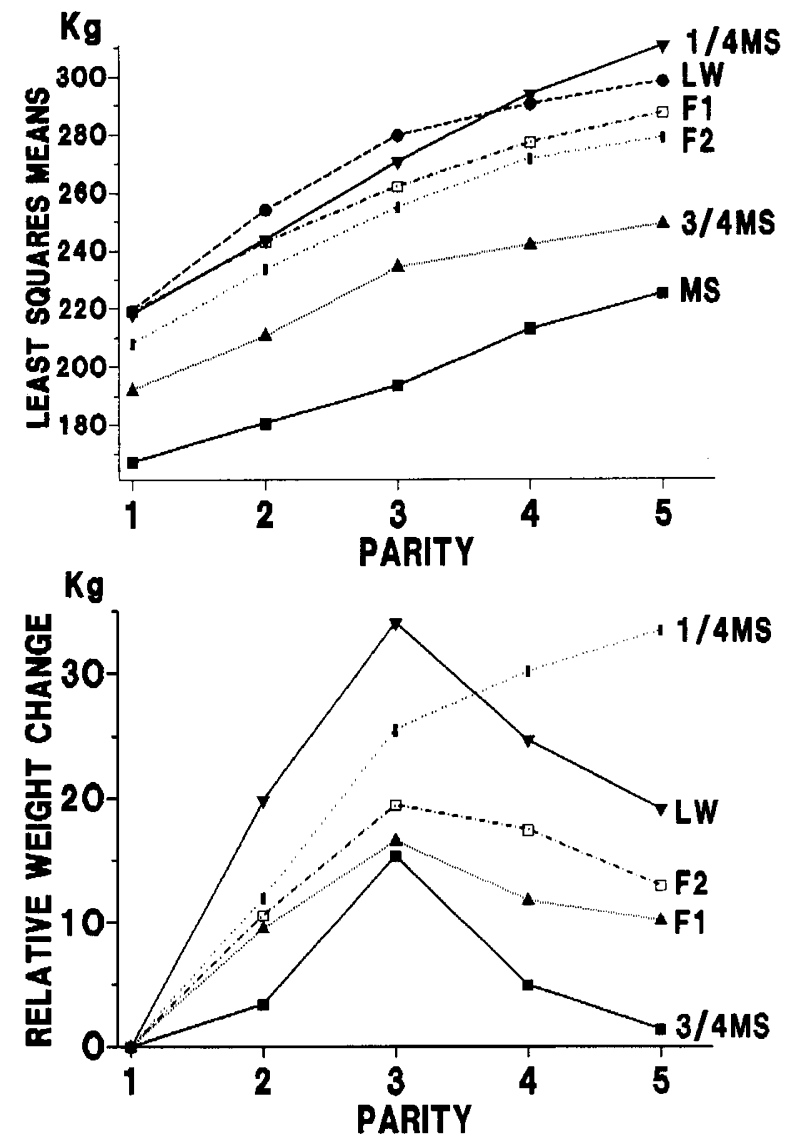

Fig 1. Evolution of sow weight before farrowing with parity. 1a - least squares means. $1 \mathrm{~b}$ - relative weight changes from the first to the fifth parity (expressed as deviations from weight changes in Meishan sows). LW : Large White, MS: Meishan, F1: LW $\times$ MS or MS $\times$ LW, F2: F1 $\times$ F1, 1/4 MS: F1 $\times$ LW or LW $\times$ F1, 3/4 MS: F1 $\times$ MS or MS $\times$ F1.

growth. Comparatively to LW, " $3 / 4 \mathrm{LW"} \mathrm{and} \mathrm{LW} \times \mathrm{MS}$, adult weight was 20 , $40-50$ and $80 \mathrm{~kg}$ lower in MS $\times$ LW or "F2", "3/4 MS" and MS respectively.

\section{Crossbreeding parameters}

Crossbreeding parameters for traits measured during the preweaning and growing periods are presented in table IV. Due to the presence of a significant genetic type $\times$ parity interaction, crossbreeding parameters for preweaning traits were also estimated for each parity.

The genetic determination of preweaning traits was mainly of maternal origin, although a direct heterosis effect on birth weight was observed. Maternal additive differences were largely in favour of LW for WB and W21. Maternal heterosis effects 


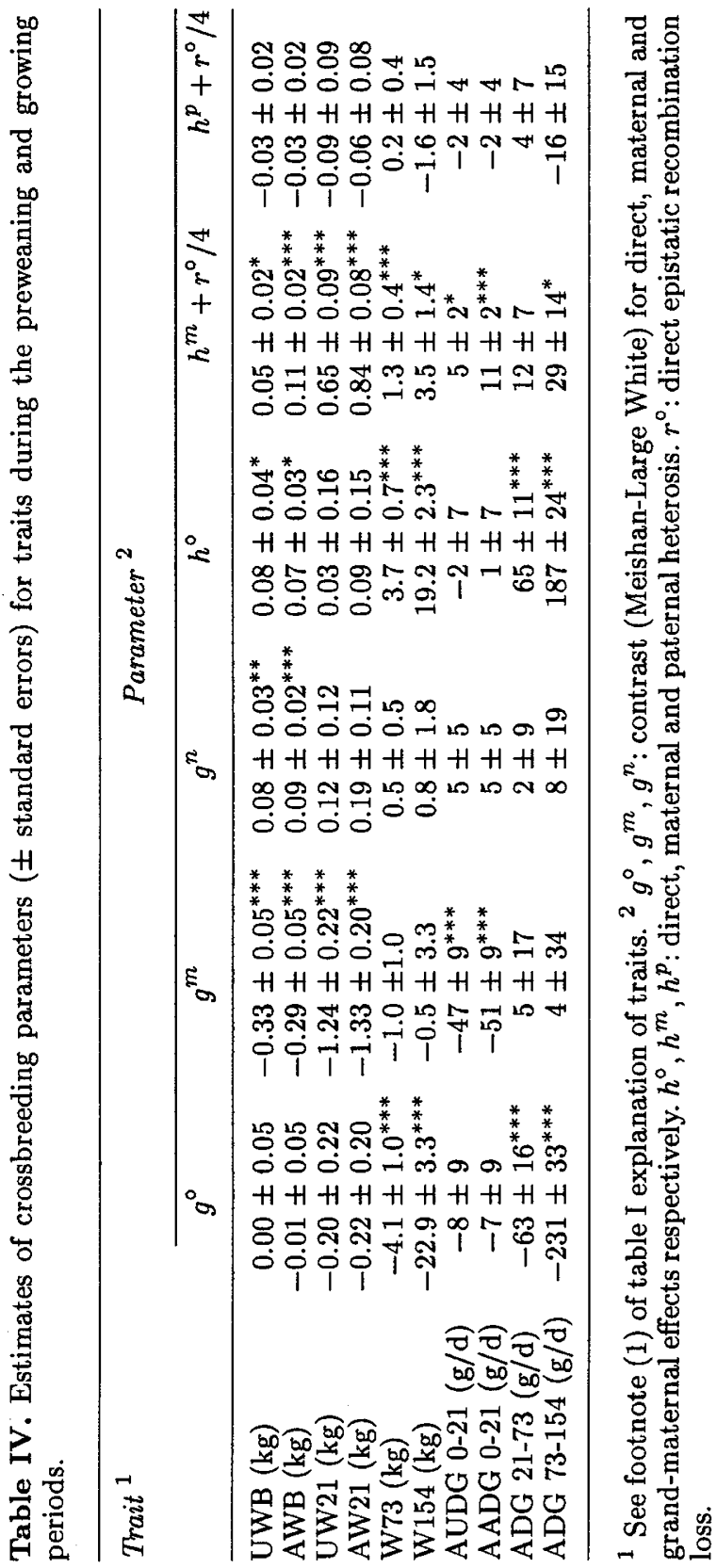


increased sharply between birth and weaning $(4,16$ and $14 \%$ for UWB, UADG 0-21 and UW21 respectively). Grand maternal and paternal heterosis effects were small and non significant, except at birth where a grand maternal difference in favour of MS was observed. Adjustment of the data for litter size slightly increased the already prominent maternal effects. Maternal differences between breeds increased between first and third parities from 0.33 to $0.42 \mathrm{~kg}$ at birth and from 0.71 to $1.58 \mathrm{~kg}$ at $21 \mathrm{~d}$ of age (fig 2).

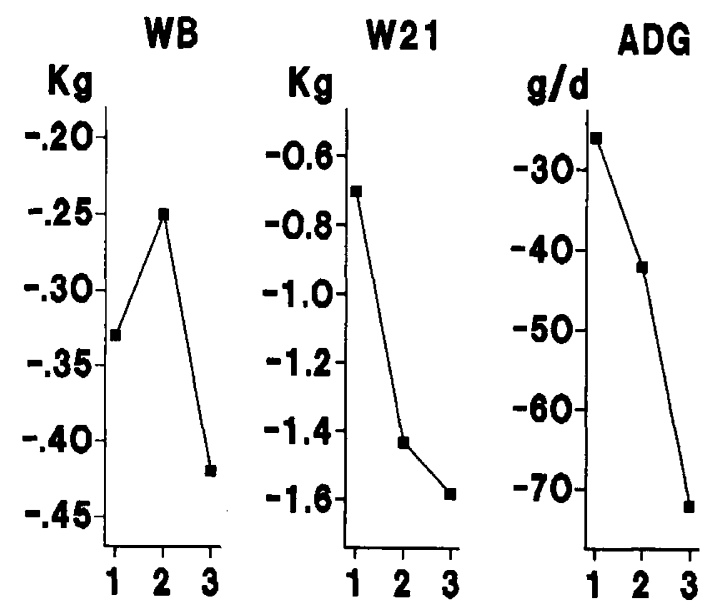

Fig 2. Evolution of additive maternal effects (Meishan-Large White) with parity for preweaning traits (traits are not adjusted for litter size). WB: weight at birth, W21: weight at $21 \mathrm{~d}$. ADG: average daily gain between 0 and 21 days.

Direct effects explained $75-95 \%$ of additive differences between breeds during the growing period versus less than $15 \%$ before weaning. Direct heterosis effects were $15 \%$ and $25 \%$ of parental mean weight for W73 and W154 respectively. Lower, although significant, maternal heterosis effects were oberved (4.5 and $3.5 \%$ of parental means for W73 and W154 respectively). The remaining parameters were small and non significant.

Direct effects also explained most of the differences between genetic types for sow weight at farrowing (table V). Direct additive differences increased with parity (58 $\pm 9 \mathrm{~kg}$ at first farrowing; $111 \pm 10 \mathrm{~kg}$ at 5 th farrowing in favour of $\mathrm{LW}$ ). The only other significant parameter was direct heterosis, which remained almost constant from the 1st to the 5 th parity and averaged $27 \pm 3 \mathrm{~kg}$.

\section{DISCUSSION}

The results of this study confirmed those previously obtained by Legault et al (1982; 1985 ) and clearly showed the poor growth performance of the French MS line as compared to a widely used European breed, the LW. Although, as stated by Bidanel et al (1989), any extrapolation to the whole MS breed should be avoided due to the 
Table V. Estimates of crossbreeding parameters ( \pm standard errors) for sow weight before farrowing $(\mathrm{kg})$.

\begin{tabular}{lccccc}
\hline Parameter $^{1}$ & Parity & \multicolumn{5}{c}{} \\
\cline { 2 - 6 } & 1 & 2 & 3 & 4 & 5 \\
\hline$g^{\circ}$ & $58 \pm 9^{* * *}$ & $72 \pm 9^{* * *}$ & $85 \pm 9^{* * *}$ & $98 \pm 10^{* * *}$ & $111 \pm 10^{* * *}$ \\
$g^{m}$ & $-11 \pm 9$ & $-6 \pm 9$ & $-8 \pm 9$ & $-8 \pm 9$ & $-12 \pm 10$ \\
$g^{n}$ & $6 \pm 5$ & $5 \pm 5$ & $2 \pm 5$ & $-3 \pm 6$ & $-8 \pm 6$ \\
$h^{\circ}$ & $27 \pm 6^{* * *}$ & $27 \pm 6^{* * *}$ & $28 \pm 7^{* * *}$ & $26 \pm 7^{* * *}$ & $26 \pm 8^{* * *}$ \\
$h^{m}+1 / 42^{\circ}$ & $0 \pm 4$ & $-3 \pm 4$ & $1 \pm 4$ & $2 \pm 4$ & $7 \pm 4$ \\
$h^{p}+1 / 42^{\circ}$ & $-1 \pm 4$ & $3 \pm 4$ & $2 \pm 4$ & $2 \pm 4$ & $-6 \pm 5$ \\
\hline
\end{tabular}

${ }^{1}$ See footnote (1) of table IV for explanation of parameters.

low number of founder animals, similar low growth rates were observed in China in comparison with the Russian Large White (Cheng, 1984; Zhang et al, 1986).

The inferiority of MS over LW was apparent from birth and increased with age. MS birth weights were higher than previous reports $(1.02 \mathrm{~kg}$ versus $0.88 \mathrm{~kg}$ and $0.93 \mathrm{~kg}$ according to Legault et al (1982) and Le Dividich et al (1990) respectively). Performance during the suckling period was similar to the results of Legault et al (1982) or Van Der Steen and De Groot (1989). The lower performance of "3/4 MS" and "F1" piglets farrowed and suckled by MS dams versus "F1" or LW sows clearly demonstrated that the maternal environment provided by MS females was limiting, at least for crossbred piglets. This disagrees with results obtained from a crossfostering experiment involving MS and Dutch breeds (Van Der Steen and De Groot, 1989). Dutch piglets had a $27 \%$ higher growth rate than MS and exhibited similar performance when suckled by MS or Dutch dams, thus indicating that the maternal environment provided by MS sows was no more limiting than that of Dutch sows and that low performance of MS piglets was mainly due to direct gene effects. It remains to be determined whether a similar situation exists during the prenatal period. Only crossed embryo transfer experiments could answer this question.

The presence of an interaction between genetic type and parity for preweaning traits is very likely to be due to differences in the maturity rate of gilts. Females with increasing proportions of MS genes reach their mature size earlier so that they probably provide a better maternal environment to their embryos and litter during the first parities.

Age related augmentation in the relative growth disadvantage of MS females compared with LW during the growing period can also be related to the large difference in the rate of maturity between the two breeds. The growth of MS was relatively high during the postweaning period, but was strongly impaired later on, the inflexion point of their growth curve being close to puberty, at $80-100 \mathrm{~d}$ of age (Legault and Caritez, 1983; Bazer et al, 1988) versus 6-7 months of age in LW (Delpech and Lefaucheur, 1986). Moreover, sexual maturity had a huge influence on appetite. Food intake was sharply reduced in MS females during the oestrous period, which is particularly long in MS (Bazer et al, 1988). In "F1" gilts, which 
also reach puberty very early (Legault and Caritez, 1983), no noticeable reduction in feed intake was observed during the oestrous period, presumably because of a shorter oestrous duration than in MS. Growth potential in "F1" was similar to or even higher than that in pure LW gilts, demonstrating the excellent combining ability of MS. Direct heterosis values for weight gain during the growing period were very high. Estimates for ADG 73-154 and W154 were more than 3 times higher than those reported in the literature (Sellier, 1976; Johnson, 1981; Bidanel, 1988). However, it may be argued that they were somewhat overestimated, since the reduction of MS appetite during oestrous tended to lower their mean performance. More generally, it may be asked whether usual growth measurements really estimate the lean growth potential of MS or whether they are only indicators of the strength of their sexual behaviour. Only the use of castrated animals would have avoided this problem.

The effects of libido are presumably much reduced on sow weights. Their general evolution with parity is similar to that obtained by Bidanel et al (1989), though no significant parity $\times$ genetic type interaction was observed in that study, and, for LW sows, to earlier results of Salmon-Legagneur et al (1966).

The general development of crossbreeding parameters through growth followed a classical pattern, with a predominant role of the sow during suckling, followed by a sharp decrease of its influence after weaning. However, several details must be mentioned. If maternal heterosis on preweaning growth had already been reported (Johnson et al, 1978; Schneider et al, 1982; Jungst and Kuhlers, 1984), its existence after weaning is less usual, as maternal effects are generally considered as negligible on growth during the growing period (Johnson, 1981; Mc Laren et al, 1987). The significant grand-maternal effects on birth weight are also in disagreement with previous results (Johnson et al, 1978). The estimates of direct heterosis on sow weight are slightly lower than those obtained in the second step of this experiment (Bidanel et al, 1989). However, they confirm that important non-additive effects are still present on sow adult weights. This parameter has seldom been estimated in pigs, but similar results have recently been reported in cattle (Dearborn et al, 1987), refuting the classical viewpoint stating that adult traits are mainly additive.

The parity-related changes in genetic parameters of sow and piglet weights are consistent with the hypothesis that the observed parity $\times$ genetic type interactions are mainly due to between breed differences in the rate of maturity. Additive difference between LW and MS for sow weight increased with parity and presumably affected their relative uterine size and milk production. The more mature MS gilts provided their best possible environment to their piglets earlier than LW gilts. This observation could also partly account for the high survival rate of piglets suckled by MS gilts.

\section{CONCLUSION}

The present study confirms and quantifies the important difference between the Meishan and the most widely used French breed, the Large White, for growth and fattening traits. These differences tend to disappear in crossbred products, due to exceptionally high direct heterosis effects on growth traits. Bidanel et al (1989) discussed several hypotheses to explain these high heterosis values. Concerning 
growth traits, another partial explanation comes from the intense sexual behaviour of Meishan that impairs their growth performance and consequently leads to some overestimation of direct heterosis effects. In a more general way, the extreme physiological characteristics of Meishan also give a new insight on the between breeds variability of maturity rate in pigs and its influence on growth performance. The main effect is on weight gain during the growing period and is to a large extent due to the early puberty and the marked sexual behaviour of Meishan. This effect questions the significance of usual growth measurements in that breed. Indirect effects also seem to exist on preweaning traits through the environment provided by the dam during the gestation and suckling periods.

Finally, the knowledge of the crossbreeding parameters for growth between Large White and Meishan breeds from birth to an advanced stage of their reproductive life is the first step in the determination of an accurate model for predicting the costs and the efficiency of growth in various genetic types involving Meishan genes. However, a precise study of the between breeds variability in the efficiency of nutrient utilization has still to be implemented.

\section{REFERENCES}

Bazer FW, Thatcher WW, Martinat-Botte F, Terqui M (1988) Sexual maturation and morphological development of the reproductive tract in Large White and prolific Chinese Meishan pigs. J Reprod Fert 83, 723-728

Bidanel JP (1988) Bases zootechniques et génétiques de l'utilisation en élevage intensif des races prolifiques chinoises - cas du porc Meishan. $194 \mathrm{p}$, Doctoral Thesis, Institut National Agronomique Paris-Grignon, France

Bidanel JP, Caritez JC, Legault C (1989) Estimation of crossbreeding parameters between Large White and Meishan porcine breeds. 1. Reproductive performance. Genet Sel Evol 21, 507-526

Cheng PL (1984) A highly prolific breed of China - The Taihu pig. Parts III and IV. Pig News and Information 5, 13-18

Dearborn DD, Gregory KE, Cundiff LV, Koch RM (1987) Heterosis and breed maternal and transmitted effects in beef cattle. V. Weight, height and condition score of females. J Anim Sci 64, 706-713

Delpech P, Lefaucheur L (1986) La croissance. In: Le porc et son élevage: bases scientifiques et techniques (Perez JM, Mornert P, Rérat A, eds) Maloine, Paris Dickerson GE (1969) Experimental approaches in utilising breed resources. Anim Breed Abstr 37, 191-202

Dickerson GE (1973) Inbreeding and heterosis in animals. In: Proceedings of the Animal Breeding and Genetics Symposium in honor of Dr JL Lush, American Society of Animal Science and Dairy Science Association, Champaign, Illinois, pp $54-77$

Henderson CR (1973) Sire evaluation and genetic trends. In: Proceedings of the Animal Breeding and Genetics Symposium in honor of Dr JL Lush, American Society of Animal Science and Dairy Science Association, Champaign, Illinois, pp $10-41$

Johnson RK (1981) Crossbreeding in swine: experimental results. $J$ Anim Sci 52, 906-923 
Johnson RK, Omtvedt IT, Walters LE (1978) Comparison of productivity and performance for two-breed and three-breed crosses in swine. J Anim Sci 46, 69-82 Jungst SB, Kuhlers DL (1984) Estimates of additive genetic, maternal and specific combining abilitites for some litter traits of swine. J Anim Sci 59, 1140-1148

Komender P, Hoeschele I (1989) Use of mixed-model methodology to improve estimation of crossbreeding parameters. Livest Prod Sci 21, 101-113

Legault C, Caritez JC, Gruand J, Sellier P (1982) Premier bilan de l'expérimentation sur le porc chinois en France. 3. Croissance et composition corporelle en croisement à deux ou trois voies. In: 1 4es Journées de la Recherche Porcine en France, Paris, 3-4 février 1982, Institut Technique du Porc, Paris, pp 127-135

Legault C, Caritez JC (1983) L'expérimentation sur le porc chinois en France. I. Performances de reproduction en race pure et en croisement. Génét Sél Évol 15, 225-240

Legault C, Sellier P, Caritez JC, Dando P, Gruand J (1985) Expérimentation sur le porc chinois en France. II. Performances de production en croisement avec les races européennes. Génét Sél Évol 17, 133-152

McLaren DG, Buchanan DS, Johnson RK (1987) Individual heterosis and breed effects for postweaning performance and carcass traits in four breeds of swine. J Anim Sci 64, 83-98

Patterson HD, Thompson R (1971) Recovery of inter-block information when block sizes are unequal. Biometrika 58, 545-554

Salmon-Legagneur E, Legault C, Aumaître A (1966) Relations entre les variations pondérales de la truie en reproduction et les performances d'élevage. Ann Zootech $15,215-229$

SAS Institute INC (1985) SAS User's Guide: Statistics, Version 5 Edition. Cary, NC: SAS Institute Inc, $956 \mathrm{p}$

Schneider JF, Christian LL, Kuhlers DL (1982) Crossbreeding in swine: genetic effect on pig growth and carcass merit. J Anim Sci 54, 747-756

Sellier P (1976) The basis of crossbreeding in pigs. A review. Livest Prod Sci 3, 203-226

Sellier P, Legault C (1986) The Chinese prolific breeds of pigs: examples of extreme genetic stocks. In: Exploitating new technologies in animal breeding: genetic development (Smith C, King JWB, McKay JC, eds) Oxford University Press, pp 153-162

Van der Steen HAM, De Groot PN (1989) Breed of sow and breed of piglet effect on milk intake and growth of piglets; Meishan versus Dutch pigs. In: 40th Annual Meeting of the EAAP, Dublin, Ireland, August 1989, Commission on pig production, $17 \mathrm{p}$

Zhang ZG, Li BT, Chen XH (1986) Pig breeds in China (in Chinese). Shanghaï Scientific and Technical Publishers 